\title{
Youth Climate Change Mitigation Practices and Adaptation in Malacca State, Malaysia
}

\author{
Nasir NAYAN 1 \\ Sultan Idris Education University,
} MALAYSIA

Yazid SALEH 4

Sultan Idris Education University, MALAYSIA

\author{
Mohmadisa HASHIM²
}

Sultan Idris Education University,

MALAYSIA

\author{
Hanifah MAHAT ${ }^{3}$ \\ Sultan Idris Education University, \\ MALAYSIA
}

\section{Saiyidatina Balkhis NORKHAIDI5}

Sultan Idris Education University, MALAYSIA

'Corresponding author: Assoc. Prof. Dr.; Department of Geography and Environment, Faculty of Human Sciences, Sultan Idris Education University, 35900 Tanjong Malim, Perak. nasir [at] fsk.upsi.edu.my ORCID: 0000-0001-8812-4320

2 Dr.; Department of Geography and Environment, Sultan Idris Education Unv. mohmadisa [at] fsk.upsi.edu.my ORCID: 0000-0001-6364-7918

3 Dr.; Department of Geography and Environment, Faculty of Human Sciences, Sultan Idris Education University, 35900 Tanjong Malim, Perak. Email: hanifah.mahat [at] fsk.upsi.edu.my, ORCID: 0000-0003-0756-6907

${ }_{4}^{4}$ Assoc. Prof. Dr.; Department of Geography and Environment, Faculty of Human Sciences, Sultan Idris Education University, 35900 Tanjong Malim, Perak. E-mail: yazid [at] fsk.upsi.edu.my, ORCID: 0000-0003-1603-9025

5 Department of Geography and Environment, Sultan Idris Education Unv. Perak. E-mail: balkhis86 [at] gmail.com, ORCID: 0000-0002-4571-4619

\section{Abstract}

Climate literacy is one way to assess youth awareness about current climate change phenomena such as El-Nino or La-Nina. This article aims to build a model of climate change mitigation practices and adaptation among youth in Malaysia, especially in the historical state of Malacca. A total of 400 youth respondents residing in the state of Malacca were selected through a simple random sampling process. Among the sub-constructs studied are sustainable development, environmental conservation, natural resources and effective involvement. The data were analyzed descriptively to pair the reliability of results from Cronbach's alpha with confirmatory factor analysis (CFA). CFA was used to obtain three solutions factor from SPSS 22 and AMOS 20 software. The results showed that the Cronbach's alpha value was at a 'high' classification which surpasses 0.80 . Results from CFA analysis shown a three-factor solution is appropriate and acceptable based on the suggested indicators. Therefore, a 30-item measurement model was developed to measure the mitigation and adaptation practices of climate change amongst youth in Malaysia. This study issignificant because few studies have been completed on connecting youth practice and adaptation in regard to climate change it; the current study illustrates how Malaccan youth practice mitigation knowledge in the era of climate change, and how they say they will adapt to the effect of climate change.

\section{Keywords}

Practices, Mitigation, Adaptation, Climate Change, Climate Literacy 

Recently, climate change has been identified as a major setback in people's lives and daily lifestyles such as heavy flood which is prevented people from going to work places. Unfortunately, the effects of climate change such as continually rising temperatures, have caused changes in the interactions occurring across the four spheres of the biophysical environment (the biosphere, atmosphere, hydrosphere, and lithosphere) which leads to adverse impacts occurring on food production and crop-yield production. Climate, by definition, is the properties of weather occurring over an extensive area for a long period of time, such as tropical, subtropical, temperate and artic. In contrast, the term weather refers to the features of weather occurring over a local area for a short period of time, such as atmospheric temperature, rainfall, moisturization and wind condition (Shaharuddin, 2006).

Climate zones usually cover a very wide area, for example tropical covers south-east Asia which includes the countries of Malaysia, Singapore, Indonesia, Brunei, Thailand, and the Philippines. The elements of climate cover the average temperature, amount of precipitation, hours of sunlight per day, and other variables. However, weather conditions are only associated with a very small area, such as Kuala Lumpur, and occur on a daily basis. Elements of the weather referred to each day includes temperature, rainfall, cloud-cover, wind speed and direction, humidity, atmospheric pressure and much more. Meanwhile, the United Nations (UN) Climate Change Panel (IPCC) report states that climate change refers to the variation in the average climate conditions for a large area, or a statistically significant long-term change to climate patterns. Climate change is an event that cannot be denied, and it can happen as a result of human activity causing a release of greenhouse gases into the atmosphere leading to increased air temperature.

Climate change caused by human activity and physical processes can adversely affects life in this world because of the rise in levels of carbon dioxide being released in to the atmosphere (Beck et al., 2013; Miler \& Sladek, 201 1; Nasir et al., 2018; Saiyidatina Balkis et al., 2017; Semenza et al., 2008; Suhana et al., 2018; Ummi Nur Asyiqeen \& Kesumawati, 2017; Veron et al., 2016). An increase in gas and other pollutants is said to be trapping and raising the temperature levels. Increased greenhouse gas concentrations in the atmosphere, especially carbon dioxide, methane, and nitrous oxide occurring from the burning fossil fuels such as petrol, diesel, coal, and land use activities, are known to trap heat and cause an increase in temperatures. Consequently, the global warming phenomena has had many negative impacts on human life today. Countries registered as being the largest carbon contributors are China, the United States, and some European countries including Germany, Spain, France or United Kingdom. Based on studies conducted by the World Resources Institute (WRI), China has released a total of 7249.8 million tons of carbon matrices a year, followed by an American company with a release rate of 7098 million tons (Norfarhana \& Muhammad Khairulanam, 2014). If the situation is prolonged, and nobody bothers to take care of it, then the earth's temperature will keep increasing, and it will trigger a continuation and exacerbation of global warming which will affect humans and all living things on earth.

From the beginning of the Industrial Revolution in Europe, human activity has drastically influenced the world by significantly contributing emissions to the 
atmosphere which then contributes to changes occurring global physical environments. The extensive use of fossil fuels has not only contributed to an increased concentration of greenhouse gases in the atmosphere, it has also caused a spike in global temperatures which has led to the development of the climate change phenomena. Many studies show that climate change processes have existed for thousands of millions of years and still occurs today; these studies also show such processes will keep occurring into the future, with the only difference being the magnitude (Shaharuddin, 2006). The United Nations' Intergovernmental Panel on Climate Change (UNIPCC) assessment report has shown that human activity has been one of the dominant factors in climate change from the mid-twentieth century in addition to natural causes (UNIPCC, 2013). If the concentration of greenhouse gases in the atmosphere continues to increase, it is expected that by the end of the 21 st century, the average temperature of the world will have risen by six degrees Celsius. This is much higher than the less than one-degree Celsius increase which has occurred over the last 100 years. If such a situation continues, the world will enter a state of destruction.

Knowledge can help individuals, groups and communities to gain experience and acquire the basic understanding that is needed to create and ensure environmental sustainability (UNESCOUNEP, 1978). According to Palmer and Neal (1994), the knowledge of environmental education can be defined as the concepts and information related to an understanding about the environment and issues affecting the environment. In this study, knowledge about environmental issues refers to the knowledge or understanding of the concepts and facts related to climate change mitigation and adaptation. Knowledge about facts is knowledge of the events that have occurred or existing situations that can be ascertained (Richmond \& Morgan, 1977). It is vital at this moment to learn more about what youth know about climate change and how they react towards changes affecting the planet because the most impacted group of people affected by climate change are the present group of youth (Kiaras \& Ben, 2018).

The knowledge component in this study is based on a statement by Brown (1991), which suggests an environmental-based knowledge concept is comprised of three components: environment, economy and social values. The environmental pillar is about the use of resources and environmental protection. The economic pillar encompasses environmental costs and benefits including emphasis on the use of sensitive natural resources during economic development, and the capacity for economic reforms about natural resource use. The social sustainability pillar emphasises topics such as engagement, independence, unity, security, equality and justice; all of which significantly affect the continuity and quality of life for people and future generations. Priority should be given to the people so that knowledge gained from environmental, economic and social aspects of emphasised in order to achieve sustainability.

This paper aims to expose the literacy of young people in Malacca State, which is significant for how the youth practice mitigation knowledge among themselves in this era of climate change. At the same time, this paper considers how they will adapt to the effect of climate change. Not many studies have been done on connecting youth practices and adaptation, particularly with respect to climate change. The output is deemed to be vital as it will also affect 
a new era of education that not only focuses on a traditional way of thinking but that also needs to address the survival of the world in the future.

\section{Methodology}

The current study employs two forms of data collection, through primary data and secondary data. Primary data were collected from the questionnaire while secondary data were collected from books, magazines, articles, journals and internet sources. The items of the questionnaire are aimed at measuring the climate change mitigation and adaptation practices amongst the youth who are residing in Malacca. Secondary data is obtained mainly from the statistics department, and was used to acquire the population data.

\section{Study Area}

The study was conducted in Malacca state, a historical city in Malaysia and the second smallest state in Peninsular Malaysia (after Perlis). Malacca has three districts, namely Alor Gajah, Jasin and Central Malacca, covering a total land area of 1,650 sq. km (Figure 1). The main towns in Malacca are Malacca City, Alor Gajah, Tanah Masjid, Jasin, Merlimau, Tampin, and Ayer Keroh. Malacca attracts tourists from within Malaysia and from overseas due to its historical elements from the eras of the Malacca Sultanate, Portuguese, Netherlands, East India Company or British and now the Malaysia Federation. People will not miss Malacca as one of the tourist destinations if they come to visit Malaysia because Malacca is only a one-hour journey from Kuala Lumpur and a two hours journey from Singapore.

\section{Population and Sample}

These respondents involved in the current study were the youth population of Malacca, Malaysia. Based on data from the Malaysia Department of Statistics (Jabatan Perangkaan Malaysia, 2010) there are 347,805 youths identified in the state of Malacca who range in age from 15 to 39 years. Of the total population, it is suggested that 379 samples are required to represent the population of a study (Krejcie \& Morgan, 1970). In this study, researchers obtained 400 selected samples through the use of simple random sampling (Table 1), therefore, respondents have been selected randomly throughout the state. 


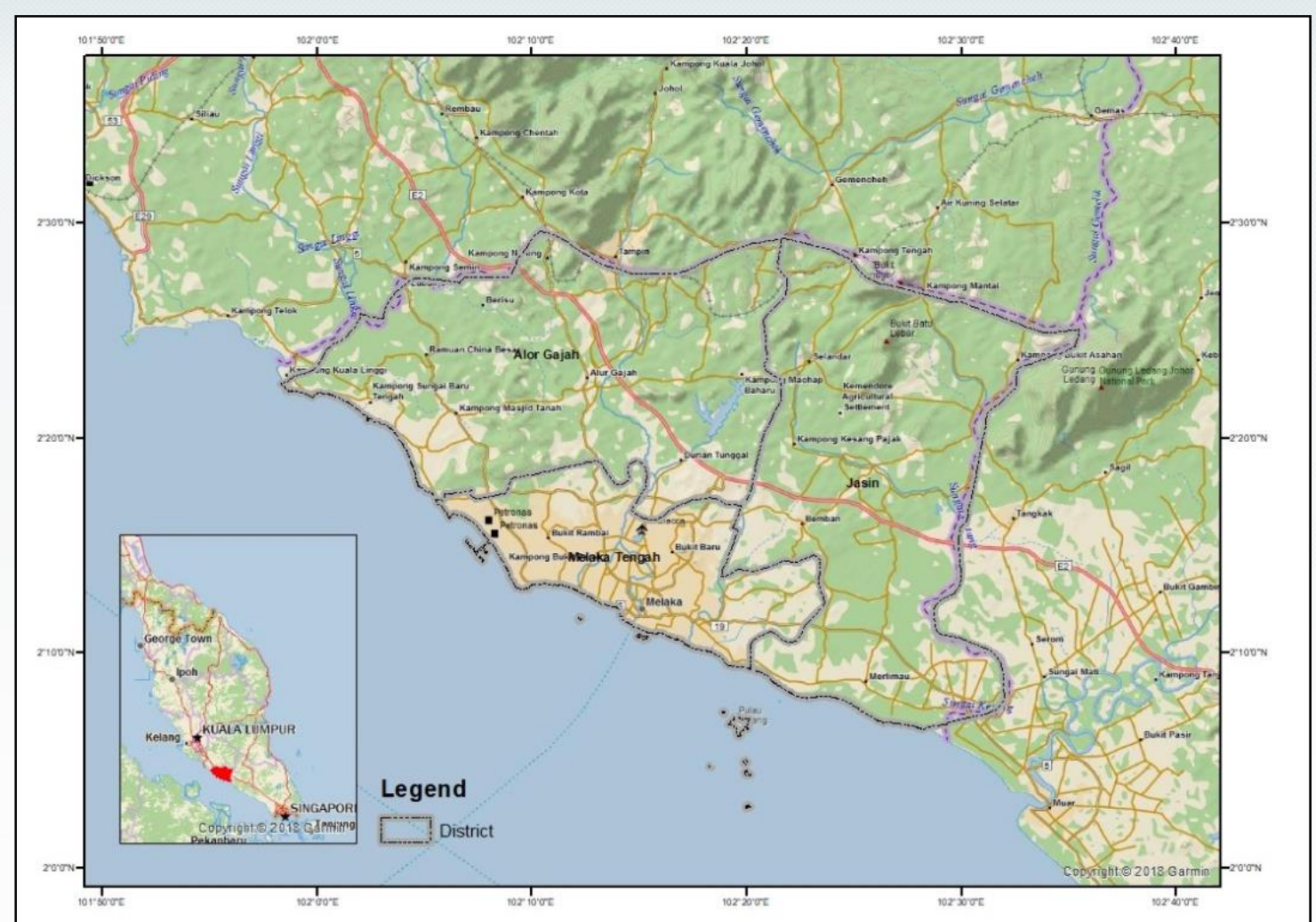

Figure 1 District in the State of Malacca

Table 1

Age, Population, Percentage and Sample Size

\begin{tabular}{llll}
\hline Age & Population & Percentage & Sample size \\
\hline $15-19$ & 92,721 & 26.7 & 107 \\
$20-24$ & 81,243 & 23.4 & 93 \\
$25-29$ & 70,330 & 20.2 & 81 \\
$30-34$ & 53,502 & 15.4 & 62 \\
$35-39$ & 50,009 & 14.4 & 58 \\
\hline Total & 347,805 & 100.0 & 400 \\
\hline
\end{tabular}

Source: Jabatan Perangkaan Malaysia (2010)

\section{Data Analysis}

In this study, two analyses were used: descriptive analysis and inferential analysis. Inferential analysis involves factor analysis. The descriptive analysis uses a mean and a percentage to describe the demographics of respondents, while inference analysis tests the item for reliability and factor analysis. The results of a reliability test for every sub-construct of the study should exceed 0.7 in order to maintain stable reliability, whereas the confirmatory factor analysis (CFA) determines the construct validity. The CFA will be used as a control for measurement based on the hypothesis factor from the Analysis of Moment Structure (AMOS 20) software. The software uses a maximum likelihood estimation to generate an estimation in the full-fledged measurement model. To examine the suitability of the measurement model matching, the index should have: (i) the minimum value of the dispute between the observed data and the hypothesized model divided by degrees of freedom (CMIN/df); (ii) comparative fit index (CFI); (iii) Lewis index (TLI); (iv) incremental-fit-index (IFI); and (V) the root mean square error of approximation (RMSEA) is being examined. Arbuckle 
(1997), Arbuckle and Wothke (1999), and Hair et al., (2006), stated that a model was an appropriate match when the compatibility index showed the following:

i. The CMIN/df with a value between 1 and 5 which is considered acceptable or an acceptable fit between model and data;

ii. The CFI, IFI and TLI indexes approaching 1.00 which show an appropriate match; and

iii. The RMSEA is .08 or less which indicates a reasonable and acceptable estimate of error.

Next, the following is to be examined if the model is found not to match:

i. Check the load factor of each item where it exceeds the recommended value according to the number of samples. The load factor describes the relationship between the latent variable with the item or indicator (Hair et al., 2006; Kline, 2005).

ii. Review the residual standards and review items with values between 2.58 and 4.00 to consider whether to keep or drop them. Items with values greater than 4.00 must be dropped.

iii. Examine the index modification to repair the model (Bryne, 2010; Hair et al., 2006; Kline, 2005). To establish the constructs of the model, a validity test of convergent and legitimate discrimination should be performed.

The convergent validity is based on the reliability of construct which has a value of 0.70 and above (Hair et al., 2006). Convergent validity can also be assessed with the item's coefficient value and the average variance extracted for a latent variable (Anderson \& Gerbing 1988; Fornell \& Larcker, 1981; Hair et al., 2006). Meanwhile, discriminant validity is assessed by comparing the squared correlations between two constructs with an average variance from the constructs. If the average variance is above the squared correlation, then discrimination validity is achieved (Hair et al., 2006). In this study, CFA was used to examine the construct validity in the study instrument.

\section{Study Instruments and Item's Development}

This study employs a questionnaire as a research instrument consisting of two parts: Section A and Section B (Table 2). Section A contains respondents' demographic information while Section B covers mitigation and adaptation practices of climate change. Table 3 shows in detail the constructs, items, and statement of this study.

Table 2

Demographic Profiles of Respondent

\begin{tabular}{|c|c|c|c|c|}
\hline Part & Description & Construct & $\begin{array}{l}\text { Number of } \\
\text { Items }\end{array}$ & Item source \\
\hline$A$ & $\begin{array}{l}\text { Demographic } \\
\text { information }\end{array}$ & $\begin{array}{l}\text { Gender } \\
\text { Race } \\
\text { Household income }\end{array}$ & $\begin{array}{l}2 \\
7 \\
6\end{array}$ & $\begin{array}{l}\text { Self-built according to the } \\
\text { needs of the study }\end{array}$ \\
\hline B & $\begin{array}{l}\text { Mitigation } \\
\text { practices and } \\
\text { climate } \\
\text { change } \\
\text { adaptations }\end{array}$ & $\begin{array}{l}\text { Sustainable } \\
\text { development } \\
\text { Environmental } \\
\text { Conservation and } \\
\text { Natural Resources } \\
\text { Effective Involvement }\end{array}$ & $\begin{array}{l}11 \\
24\end{array}$ & $\begin{array}{l}\text { Modified from Stacy (2016), } \\
\text { Hanifah \& Mohmadisa } \\
\text { (2016), Hanifah, Nasir, Yazid } \\
\text { \& Mohmadisa (2017) and } \\
\text { Kementerian Sumber Asli } \\
\text { dan Alam Sekitar Malaysia } \\
\text { (2010) }\end{array}$ \\
\hline
\end{tabular}


Table 3

Constructs, Items and Statement

\begin{tabular}{|c|c|c|}
\hline Construct & Items & Statement \\
\hline \multirow{11}{*}{$\begin{array}{l}\text { Sustainable } \\
\text { development }\end{array}$} & al. & I address climate change by planting trees \\
\hline & a2. & I do not pick the leaves/flowers at will \\
\hline & a3. & I built a green space like a herb garden \\
\hline & a4. & I did not burn the trash openly \\
\hline & a5. & I reuse the items that can be recycled \\
\hline & ab. & I remove waste that can be recycled into the recycle bin \\
\hline & a7. & I use a handkerchief instead of tissue \\
\hline & a8. & I use a rechargeable battery \\
\hline & a9. & I brought food supplies from home in food containers \\
\hline & alo. & I use both sides of the paper while writing \\
\hline & all. & $\begin{array}{l}\text { I collect items that can be recycled for sale to recycling } \\
\text { collectors }\end{array}$ \\
\hline \multirow{13}{*}{$\begin{array}{l}\text { Environmental } \\
\text { Conservation and } \\
\text { Natural Resources }\end{array}$} & al2. & I switch off the fan when not in use \\
\hline & al3. & I switch off the fan when it was raining \\
\hline & al4. & I keep the electrical switch off even when not in use \\
\hline & a 15. & I switch off the unused room lights \\
\hline & al6. & $\begin{array}{l}\text { I make sure the windows are open for a good room } \\
\text { ventilation }\end{array}$ \\
\hline & al7. & I always clean the fan and the lamp from the dirt/fence \\
\hline & al8. & I use energy-efficient electrical equipment \\
\hline & al9. & I switch off the bedroom light when I go to sleep \\
\hline & a20. & I go to a location when it only necessary \\
\hline & a21. & I plan my journey in order with places \\
\hline & a22. & $\begin{array}{l}\text { I prefer walking rather than using a motorcycle or a car to } \\
\text { go to a nearby place around my house }\end{array}$ \\
\hline & a23. & $\begin{array}{l}\text { I chose to use public transport (bus, train) rather than private } \\
\text { vehicles (cars, motorcycles) }\end{array}$ \\
\hline & $a 24$. & I use petrol/diesel with no lead for my vehicles \\
\hline \multirow{6}{*}{$\begin{array}{l}\text { Effective } \\
\text { involvement }\end{array}$} & a25. & I get involved with climate change activities \\
\hline & a26. & $\begin{array}{l}\text { I actively involved in climate change issue awareness } \\
\text { campaign }\end{array}$ \\
\hline & a27. & I became a volunteer in climate change issues activities \\
\hline & a28. & $\begin{array}{l}\text { I have a full commitment to any related climate change } \\
\text { programs }\end{array}$ \\
\hline & a29. & $\begin{array}{l}\text { I cooperate with authorities to tackle climate change } \\
\text { problems }\end{array}$ \\
\hline & a30. & $\begin{array}{l}\text { I obey with the activities that involve in environmental } \\
\text { conservation and climate change issue }\end{array}$ \\
\hline
\end{tabular}

\section{Reliability and Validity of the Questionnaire}

Table 4 shows the reliability of construct and sub-construct for mitigation and adaptation practices of climate change with the value of Cronbach's alpha which measures the internal consistency of variables. According to Babbie (1992), Cronbach's alpha values are classified in response to a reliability index classification where a value of 0.90-1.00 is 'very high', 0.70-0.89 is 'high', 0.30-0.69 is 'simple' and $0.00-0.30$ is 'low'. The results of the analysis show that the Cronbach's alpha value has a 'high' and 'very high' classification because it exceeds 0.80. The instrument of this study has high reliability according to Babbie's (1992) classification. 
Table 4

Questionnaire Reliability

\begin{tabular}{|c|c|c|c|c|}
\hline Construct & Subconstruct & & $\begin{array}{l}\text { Number of } \\
\text { Items }\end{array}$ & $\begin{array}{l}\text { Cronbach alpha } \\
\text { value }\end{array}$ \\
\hline Mitigation & Sustainable development & & 11 & .900 \\
\hline $\begin{array}{l}\text { Climate Change } \\
\text { Adaptation }\end{array}$ & $\begin{array}{l}\text { Environmental and } \\
\text { resources conservation }\end{array}$ & natural & 24 & .906 \\
\hline Practices & Effective involvement & & 30 & .937 \\
\hline
\end{tabular}

\section{Results and Discussion}

\section{Youths' Demographic Background}

Table 5 shows the 400 respondents' demographic profiles: 195 male (48.8\%) and 205 (51.2\%) female respondents. Among the respondents there were seven ethnic groups, namely 330 (82.5\%) Malays, followed by 37 Chinese (9.3\%), 19 (4.8\%) Indians and the rest were from Orang Asli, Sabah and Sarawak heritage. The last aspect studied in this demographic segment was household income. Out of 400 respondents, the majority of households, 156 respondents (39\%), had a household income of RM 1,000-RM 3,000. This was followed by 101 persons (25.3\%) having a household income of RM 3,001-RM 5,000. There were only three respondents (0.8\%) whose household income exceeded RM 20,000.

Table 5

Respondent Background

\begin{tabular}{lll}
\hline Respondent information & Number of respondents & Percentage (\%) \\
\hline Gender & 195 & 48.8 \\
Male & 205 & 51.2 \\
Female & & \\
\hline Ethnicity & 330 & 82.5 \\
Malay & 37 & 9.3 \\
Chinese & 19 & 4.8 \\
Indian & 1 & 0.3 \\
Sarawak & 9 & 2.3 \\
Sabah & 3 & 0.8 \\
Indigenous & 1 & 0.3 \\
Others & & \\
\hline Household income & 52 & 13 \\
Less than RM 1,000 & 156 & 39 \\
RM 1,000 - RM 3,000 & 101 & 25.3 \\
RM 3,001 - RM 5,000 & 60 & 15 \\
RM 5,001 - RM10,000 & 28 & 7 \\
RM 10,001 - RM 20,000 & 3 & 0.8 \\
More than RM 20,0000 & & \\
\hline
\end{tabular}

Exploratory Factor Analysis (EFA) on the Construct of Mitigation Practices and Climate Change Adaptation

The result of the EFA on climate change adaptation and mitigation practices from anti-correlation analysis procedures show a correlation coefficient value higher than 0.5. This value illustrates that factor analysis can be further analyzed. Measurement adequacy of Kaiser-Meyer-Olkin (KMO) sampling and Bartlett's test of sphericity showed that the KMO value was 0.923 , while the Bartlett's sphericity test was significant with its chi-squared value of 7912.502 and degree of freedom of 435 (Table 6). 
Table 6

Fitness Test for Factor Analysis and Uniformity of KMO Items and Bartlett's Test on Constructs of Mitigation and Climate Change Adaptation Practices

\begin{tabular}{|c|c|c|}
\hline Kaiser-Meyer-Olkin & $\begin{array}{l}\text { The measure of Sampling } \\
\text { Adequacy }\end{array}$ & 0.923 \\
\hline Bartlett's Test of Sphericity & $\begin{array}{l}\text { Approx. } \\
\text { Sphericity } \\
\text { Df } \\
\text { Sig. }\end{array}$ & $\begin{array}{l}7912.502 \\
435 \\
.000\end{array}$ \\
\hline
\end{tabular}

Factor Analysis was done to determine the number of factors to be extracted into the four categories shown in the questionnaire. Table 7 shows the matrix component with varimax rotation. The varimax rotation method is performed because it reduces the number of complex variables and increases the expected yield. The result shows that items a4, a13, a23, and a24 were dropped because they had an anti-image correlation matrix with a value of less than 0.5. Whereas for effective involvement, the values of a1, a2, a3, a5, a6, a7, a8, a9, a 10 and $a 11$ should be grouped into category 1 (sustainable development), a12, a14, a15, a16, a17, a18, a19, a20, a21 and a22 into category 2 (environmental conservation and natural resources), and then a25, a26, a27, a28, a29 and a30 belong to category 3 . The values shown in Table 7 are the coefficients or the loading factor for every item that tends to be stacked on each other. The value also shows the correlation between the item and the formed factor, and this is the key to understanding the nature of these factors.

Table 7

Matrix Component with Varimax Rotation for Constructs of Climate Change Mitigation and Adaptation Practices

\begin{tabular}{|c|c|c|c|}
\hline \multirow[b]{2}{*}{ Item } & \multicolumn{3}{|l|}{ Sub Construct } \\
\hline & $\begin{array}{l}\text { Sustainable } \\
\text { development }\end{array}$ & $\begin{array}{l}\text { Environmental and } \\
\text { Natural Resources } \\
\text { Conservation }\end{array}$ & Effective involvement \\
\hline al & .588 & & \\
\hline a2 & .521 & & \\
\hline a3 & .595 & & \\
\hline a5 & .745 & & \\
\hline$a b$ & .677 & & \\
\hline$a 7$ & .567 & & \\
\hline a8 & .597 & & \\
\hline a9 & .677 & & \\
\hline a10 & .525 & & \\
\hline all & .700 & & \\
\hline a12 & & .772 & \\
\hline al4 & & .610 & \\
\hline a15 & & .806 & \\
\hline al6 & & .759 & \\
\hline al7 & & .620 & \\
\hline a 18 & & .685 & \\
\hline a19 & & .720 & \\
\hline$a 20$ & & .779 & \\
\hline a21 & & .732 & \\
\hline a22 & & .541 & \\
\hline$a 25$ & & & .807 \\
\hline$a 26$ & & & .854 \\
\hline$a 27$ & & & .827 \\
\hline$a 28$ & & & .836 \\
\hline
\end{tabular}


Nayan, N., Hashim, M., Mahat, H., Saleh, Y \& Norkhaidi, S.B. (2020) / Youth Climate Change...

a29

a30

\section{4}

695

\section{Confirmatory Factor Analysis (CFA) for Constructs of Climate Change Mitigation and} Adaptation Practices

After the EFA was carried out for a group of items related to the mitigation and climate change adaptation practices, the Confirmatory Factor Analysis (CFA) process was carried out using the AMOS 20 software to determine the first and second climate change factor analysis model. Figure 2 shows the first stage of the CFA model construction of climate change mitigation and adaptation practices which have achieved good matching accuracy. Figure 3 is a secondtier CFA model where this model combines all dimensions of the climate change mitigation and adaptation practices maintained in the first stage analysis.

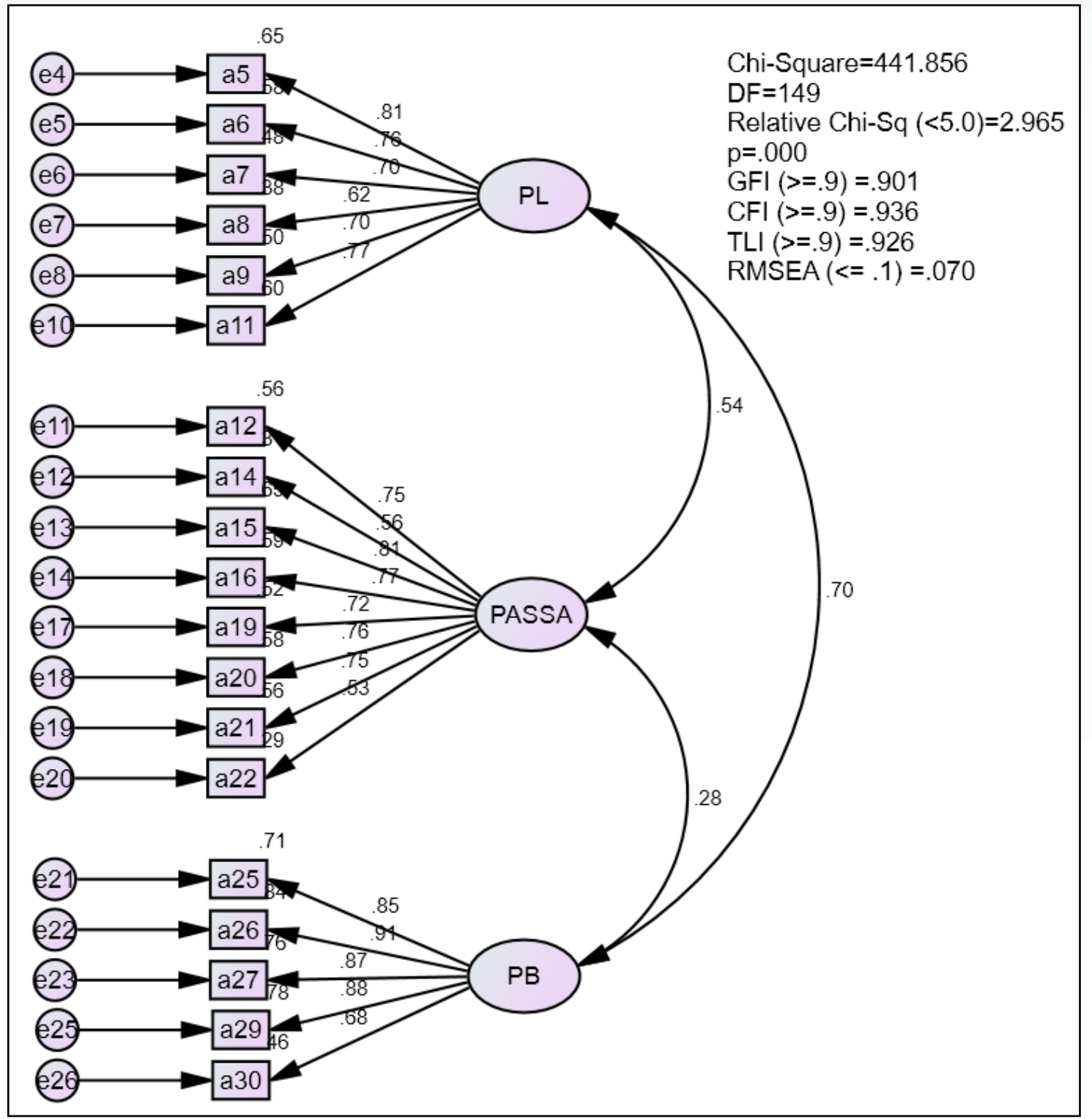

Figure 2. First stage of the CFA Model for Mitigation Practices and Adaptation of Climate Change 
The model analysis in Figure 2 and Figure 3 shows that the model has reached a good level of compatibility based on the indicated instructions (CMIN = 441.856, $\mathrm{DF}=149, \mathrm{CMIN} / \mathrm{DF}=2.965, \mathrm{p}=.000, \mathrm{GFI}=.901, \mathrm{CFI}=.936, \mathrm{TLI}=.926$, and RMSEA $=.07)$. Hence, the items and models of the second-stage Confirmatory Factor Analysis (CFA) of climate change mitigation and adaptation practices can be further used to measure the level of climate change mitigation and adaptation practices, as well as to develop a structured equation model of climate change adaptation and mitigation practices amongst youth in Malaysia, as defined by Hair et al., (2006), Anderson and Gerbing (1988), and Fornell and Larcker (1981).

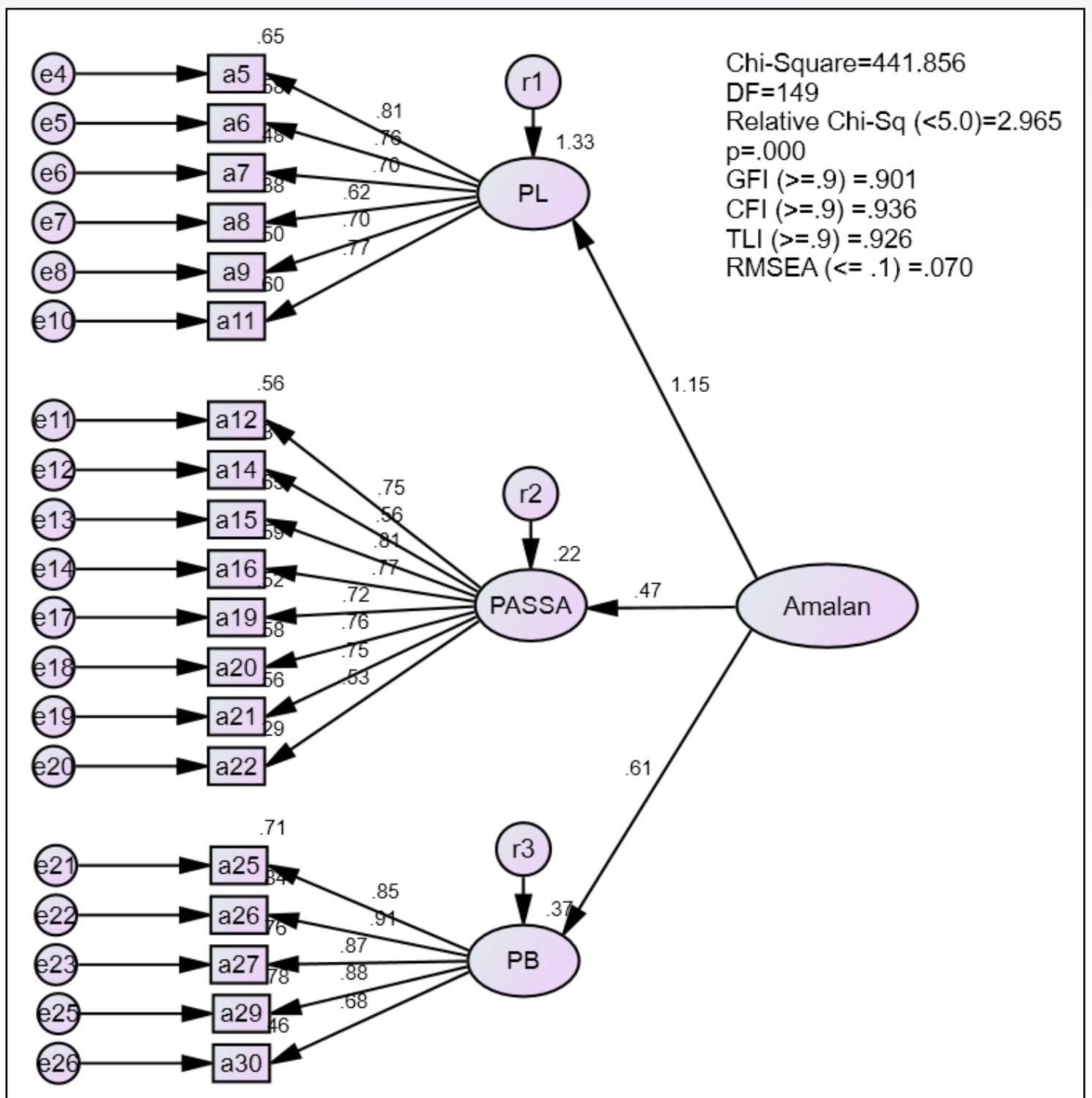

Figure 3. Second Stage of the CFA Model for Mitigation Practices and Adaptation of Climate Change 


\section{Conclusions and Recommendations}

The EFA and CFA results show that convergent validity and legitimate discrimination can be achieved in this study. EFA results show that three categories of climate change mitigation and adaptation practices have been created: sustainable development; environmental conservation; and natural resources and effective engagement. Items were dropped through this analysis. Out of the 30 initial items constructed by the researchers, 19 items were received for a good compatibility index while another 11 items were dropped. The corresponding values are $\mathrm{CMIN}=441.856, \mathrm{DF}=149, \mathrm{CMIN} / \mathrm{DF}=2.965$, $\mathrm{p}=.000, \mathrm{GFI}=.901, \mathrm{CFI}=.936, \mathrm{TLI}=.926$ and $\mathrm{RMSEA}=.07$ are in line with the set conditions. Overall, the results from this CFA process can be used to measure the level of climate change mitigation practices and adaptation practices enacted by youth in Malacca, Malaysia.

\section{Acknowledgement}

The authors would like to thank the Universiti Pendidikan Sultan Idris (UPSI) and Research Management and Innovation Center (RMIC) for the publication research fund.

\section{References}

Anderson, J., \& D, Gerbing. (1988). Structural equation modeling in practice: A review and recommended a two-step approach. Psychological Bulletin, 103(3), 411-423.

Arbuckle, J. L., \& W, Wothke. (1999). AMOS users guide version 4.0. Chicago, IL: Small Water.

Babbie, E. (1992). The Practice of Social Research. CA: Wadsworth, Inc.

Beck, A., Sinatra, G. M., \& Lombardi, D. (2013). Leveraging Higher-Education Instructors in the Climate Literacy Effort: Factors Related to University Faculty's Propensity to Teach Climate Change. International Journal of Climate Change: Impacts and Responses, 4(4), 1-17.

Brown, L. D. (1991). Bridging organizations and sustainable development. Boston University: Institute for Development Research. Retrieved from http://www.worlded.org/docs/Publications/idr/pdf/8-4.pdf.

Bryne, B. M. (2010). Structural Equation Modeling with AMOS: Basic concepts, applications, and programming. New Jersey: Lawrence Erlbaum Associates Publishers.

Fornell, C. \& Larcker, D. (1981). Evaluating structural equation models with unobserved variable and Measurement Error. Journal of Marketing Research, 18, 39-50.

Hair, J., Black, W., Babin, B., Anderson, R. \& Tatham, R. (2006). Multivariate data analysis. ( $6^{\text {th }}$ ed). New Jersey: Pearson Educational International.

Hanifah Mahat \& Mohmadisa Hashim. (2016). Analisis jejak karbon dan amalan kelestarian dalam penjimatan tenaga di sekolah rendah Daerah Batang Padang, Perak. (Research Report Universiti Pendidikan Sultan Idris) (Unpublished) (In Malay).

Hanifah Mahat, Shaharudin Idrus, Mohmadisa Hashim, Nasir Nayan, \& Yazid Salleh. (2015). Transforming Sustainability Development Education in Malaysian Schools through Greening Activities. Review of International Geographical Education Online ORIGEO, 5(1), 78-94.

Inter-Governmental Panel on Climate Change (IPCC), (2013). Climate Change: The Physical Science Basis. Contribution of Working Group I to the Fifth Assessment Report of the Intergovernmental Panel on Climate Change. In Stocker, T.F., D. Qin, G.- K. Plattner, M. Tignor, S.K. Allen, J. Boschung, A. Navels, Y. Xia, V. Bex and P.M. 
Midgley (Eds.). Cambridge University Press, Cambridge, United Kingdom, and New York, NY, USA, 1535 pp.

Jabatan Perangkaan Malaysia. (2010). Data belia mengikut negeri. Wilayah Persekutuan Putrajaya: Jabatan Perangkaan Malaysia. (In Malay).

Kementerian Sumber Asli dan Alam Sekitar Malaysia. (2010). Dasar Perubahan Iklim Malaysia. Putrajaya: Kementerian Sumber Asli dan Alam Sekitar Malaysia. (In Malay).

Kiaras Gharabagi \& Ben Anderson-Nathe. (2018). Children and youth in the era of climate change. Child \& Youth Services, 39(4), 207-210. Doi:10.1080/0145935X.2018.1557882.

Kline, R. B. (2005). Principles and practice of structural equation modeling. (2 ${ }^{\text {nd }}$ ed). New York: The Guilford Press.

Krejcie, R.V. \& Morgan, D.W. (1970). Determining sample size for research activities. Educational and Psychological Measurement, 30, 607-610.

Miler, T., \& Sladek, P. (2011). The climate literacy challenge. Procedia Social and Behavioral Sciences, 1 (12), 150-156.

Nasir Nayan, Hanifah Mahat, Mohmadisa Hashim, Yazid Saleh \& Saiyidatina Balkis Norkhaidi. (2018). Verification of the Instrument of Climate Literacy Knowledgeamong Future Teachers: Confirmatory Factor Analysis (CFA). International Journal of Academic Research in Progressive Education and Development, 7(3), 26-39.

Norfarhana Mazlan \& Muhammad Khairulanam. (2014). Pembebasan Gas Rumah Hijau. Kuala Lumpur: Dewan Bahasa dan Pustaka. (In Malay).

Palmer, J. A., \& Neal, P. (1994). The handbook of environmental education. London \& New York: Routledge.

Richmond, James M; Morgan, R. F. (1977). A national survey of the environment knowledge \& attitudes of fifth year pupils in England. England: Information Reference Centre, The Ohio State University.

Saiyidatina Balkhis Norkhaidi, Hanifah Mahat, Mohmadisa Hashim, Nasir Nayan \& Yazid Saleh. (2017). Literasi Karbon dalam kalangan Pelajar Sekolah Menengah Rendah: Kajian Kes di Wilayah Persekutuan Putrajaya. Sains Humanika, 2. Retrived from https://www.researchgate.net/publication/316190378_Sains_Humanika_Literasi_K arbon_dalam_kalangan_Pelajar_Sekolah_Menengah_Rendah_Kajian_Kes_di_Wila yah_Persekutuan_Putrajaya. (In Malay).

Semenza, J. C., Hall, D. E., Wilson, D. J., Bontempo, B. D., Sailor, D. J., \& George, L. A. (2008). Public perception of climate change. Voluntary mitigation and barriers to behavior change. American Journal of Preventive Medicine, 35(5), 479-487.

Shaharuddin Ahmad. (2006). Meteorologi. Bangi: Universiti Kebangsaan Malaysia. (In Malay)

Smorti, S., Peters-Algie, M., \& Rau, C. (2013). Engaging student teachers in sustainable praxis in Aotearoa/New Zealand. Journal of Teacher Education for Sustainability, 15 (1), 5-10.

Stacy, A.A.H. (2016). Knowledge, attitudes and practices study on climate change adaptation \& mitigation in Guyana. United Nations Development Programme (UNDP). Research report.

Suhana Saad, Tuan Fazliyanna Tuan Kamarudin, \& Abd. Hair Awang. (2018). Pengetahuan dan sokongan belia terhadap dasar kerajaan mengenai perubahan iklim. Journal of Society and Space, 14 (1), 130-141. (In Malay). 
Ummi Nur Asyiqeen Zulkefly dan Kesumawati A. Bakar (2017). Analisis Wacana Kritis terhadap Isu Perubahan Iklim di Malaysia. Jurnal Linguistik, 21 (2), 36-47. (In Malay).

UNESCO-UNEP. (1978). The Tiblisi Declaration. Connect, 3(1), 1-8.

Veron, D. E., Marbach-Ad, G., Wolfson, J., \& Ozbay, G. (2016). Assessing Climate Literacy Content in Higher Education Science Courses: Distribution, Challenges, and Needs. Journal of College Science Teaching, 45(6), 43-49. Retrieved from https://search.proquest.com/openview/2a2d758cbd6227d01761af5b757314ea/1 ?pq-origsite $=$ gscholar $\& \mathrm{cbl}=49226$.

\section{Biographical statements}

Nasir NAYAN is an Associate Professor at Department of Geography and Environment, Faculty of Human Science, Universiti Pendidikan Sultan Idris (UPSI). His field of interest are Physical Geography, Enviroment Management, Geographic Information Systems (GIS), Geography Education, Environment Education, Remote Sensing, Ecosystems, Ecology and Coastal Zone.

Mohmadisa HASHIM is a senior lecturer at Department of Geography and Environment, Faculty of Human Science, Universiti Pendidikan Sultan Idris (UPSI). His field of specialization are Physical Geography and Hydrogeomorphology.

Hanifah MAHAT is a senior lecturer at Department of Geography and Environment, Faculty of Human Science, Universiti Pendidikan Sultan Idris (UPSI) since 2014. Her field of specialization are Human Geography and Education for Sustainable Development.

Yazid SALEH is an Associate Professor at Department of Geography and Environment, Faculty of Human Science, Universiti Pendidikan Sultan Idris (UPSI). His field of specialization are Urban Geography Urban Conservation Cultural and Heritage Tourism Urban Studies.

Saiyidatina Balkhis NORKHAIDI is a PhD candidate at Department of Geography and Environment, Faculty of Human Science, Universiti Pendidikan Sultan Idris (UPSI). Her field of study is in environment education. 